\title{
Effect of Nutrient Depletion on Sensitivity of Pseudomonas cepacia to Phagocytosis and Serum Bactericidal Activity at Different Temperatures
}

\author{
By HOSMIN ANWAR, MICHAEL R. W. BROWN* AND \\ PETER A. LAMBERT \\ Microbiology Research Group, Department of Pharmacy, University of Aston in Birmingham, \\ Birmingham B4 7ET, U.K.
}

(Received 10 December 1982; revised 12 February 1983)

\begin{abstract}
Pseudomonas cepacia grown under different specific nutrient depletions in batch culture showed varying degrees of sensitivity to engulfment and killing by human polymorphonuclear leukocytes (PMN) and to killing by human serum. Resistance to killing by the combined action of PMN and serum in whole blood was found to increase in the following order of depletions: glucose $<$ iron $<$ sulphate $<$ phosphate or ammonium $<$ magnesium. There was also an increase in resistance to killing by whole blood with decrease in temperature, except that carbon-depleted cells remained very sensitive irrespective of temperature. Cells in the exponential phase of growth also showed a consistent increase in resistance as the temperature was decreased. Similar, but smaller effects were observed with oxygen-depleted cells. The increase in killing by whole blood as the phagocytic temperature was raised correlated with an increase in the number of bacteria ingested per PMN. A pattern of serum sensitivity was observed with cells grown under different nutrient depletions similar to that for whole blood. But in all cases whole blood was 6 to 10 times more effective than serum alone in killing the cells at $37^{\circ} \mathrm{C}$.
\end{abstract}

\section{INTRODUCTION}

Pseudomonas cepacia, originally described as a plant pathogen (Ballard et al., 1970), is appearing more frequently in the medical literature as a causative agent of human disease (Phillips \& Eykyn, 1971; Speller et al., 1971; Garvey \& Neu, 1975; Weinstein et al., 1976).

We have studied phenotypic factors affecting the susceptibility of the organism to killing by whole human blood, presumed to result from the combined action of phagocytes and serum. In infection there is often an elevated body temperature and host resistance is increased by enhancement of the bactericidal action of blood against certain organisms (Roberts, 1979; Mackowiak et al., 1982). An increased bactericidal capacity of polymorphonuclear leukocytes (PMN) at $40{ }^{\circ} \mathrm{C}$ relative to $37^{\circ} \mathrm{C}$ was observed with Escherichia coli, Salmonella typhimurium and Listeria monocytogenes but not with Staphylococcus aureus (Mandell, 1975; Roberts \& Steigbigel, 1977). Therefore we investigated the effect of temperature upon the phagocytosis of $P$. cepacia in whole blood.

The cell envelope of bacteria plays a crucial role in drug resistance (Brown, 1975, 1977) and currently it is suggested to play a significant role in human infection (Beveridge, 1980; Costerton et al., 1979; Smith, 1977). Van Oss and his associates (Van Oss et al., 1975; Van Oss, 1978), by contact angle measurements, and Stendahl et al. (1979), by hydrophobic interaction chromatography, concluded that the hydrophobicity of the bacterial surface relative to that of the PMN plays a crucial role in the ingestion of the bacteria by PMN.

Finch \& Brown (1978) reported the effect of nutrient limitation of Pseudomonas aeruginosa

Abbreviation: PMN, polymorphonuclear leukocyte(s). 
grown in the chemostat on the killing by rabbit PMN and cationic proteins derived from the PMN. They found that slow-growing $\left(D=0.05 \mathrm{~h}^{-1}\right)$ magnesium-limited cells were significantly more resistant to the lethal effects of PMN than were fast-growing magnesium-limited cells $\left(D=0.5 \mathrm{~h}^{-1}\right)$ and slow-growing carbon-limited cells $\left(D=0.05 \mathrm{~h}^{-1}\right)$. There is now much evidence that lack of free iron plays an important role in infection (Weinberg, 1978; Bullen, 1981). In this paper, we report the effects of various nutrient depletions in batch culture on the subsequent killing of $P$. cepacia both by serum alone and by PMN in whole blood at different temperatures.

\section{METHODS}

Bacteria and culture conditions. The organism used throughout this study was Pseudomonas cepacia NCTC 10661. Cells were grown in chemically defined medium containing: glucose, $20 \mathrm{~mm} ; \mathrm{NaCl}, 3 \mathrm{~mm} ; \mathrm{KCl}, 3 \mathrm{~mm}$; $\left(\mathrm{NH}_{4}\right)_{2} \mathrm{SO}_{4}, 12 \mathrm{mM} ; \mathrm{MgSO}_{4}, 3.2 \mathrm{mM} ; \mathrm{K}_{2} \mathrm{HPO}_{4}, 1.2 \mathrm{~mm} ; \mathrm{FeSO}_{4}, 0.02 \mathrm{~mm} ; 3$-( $N$-morpholino)propanesulphonic acid (MOPS), $50 \mathrm{~mm} ; \mathrm{pH}$ adjusted to 7.4 with $\mathrm{NaOH}$. All medium components were of Analar grade and were sterilized separately by autoclaving. To obtain the various nutrient depletions, concentrations were reduced as follows to allow growth to an optical density of only 1.0 at $470 \mathrm{~nm}: \mathrm{Mg}^{2+}$ to $0.019 \mathrm{mM}, \mathrm{Fe}^{2+}$ to $4 \times 10^{-5} \mathrm{mM}$, $\left(\mathrm{NH}_{4}\right)^{+}$to $2.2 \mathrm{mM}$, glucose to $4 \mathrm{mM},\left(\mathrm{PO}_{4}\right)^{3-}$ to $0.06 \mathrm{mM},\left(\mathrm{SO}_{4}\right)^{2-}$ to $0.15 \mathrm{~mm}$. For sulphate depletion $\mathrm{MgSO}_{4}$ was replaced by $\mathrm{MgCl}_{2}(0.16 \mathrm{mM}), \mathrm{FeSO}_{4}$ was replaced by $\mathrm{FeCl}_{2}(0.27 \mathrm{~mm})$, and MOPS buffer was replaced by phosphate buffer $\left(\mathrm{NH}_{4}\right)_{2} \mathrm{HPO}_{4}, 18 \mathrm{mM}$ and $\mathrm{NH}_{4} \mathrm{H}_{2} \mathrm{PO}_{4}, 0.48 \mathrm{mM}$. Growth was in an orbital shaker at $37^{\circ} \mathrm{C}$ for $24 \mathrm{~h}$ (stationary phase) or for exponential-phase cells to an optical density of 0.5 at $470 \mathrm{~nm}$. Cells grown to stationary phase in complete chemically defined medium were designated oxygen-depleted. Bacteria were harvested by centrifugation at $8000 \mathrm{~g}$ for $10 \mathrm{~min}$, washed once with normal saline and resuspended in sterile normal saline to an $\mathrm{OD}_{470}$ of $0 \cdot 2$.

Glassware. Glassware was washed in Extran $300(\mathrm{BDH})$, rinsed in distilled water, then in $1 \%(\mathrm{v} / \mathrm{v}) \mathrm{HCl}$, and finally rinsed thoroughly in double distilled water.

Serum bactericidal assays. Fresh venous blood was obtained from a single volunteer. Serum was separated by centrifugation at $3000 \mathrm{~g}$ for $5 \mathrm{~min}$. To $0.5 \mathrm{ml}$ of human serum in a capped polypropylene tube, $0.5 \mathrm{ml}$ of the $P$. cepacia suspension was added. The mixture was incubated at $37^{\circ} \mathrm{C}$ in a water bath shaking at 120 r.p.m., and at intervals $0 \cdot 1 \mathrm{ml}$ samples were taken, diluted with nutrient broth and the viable counts determined by the method of Miles \& Misra (1938). Each experiment was done in triplicate.

Interaction of bacteria with PMN in whole blood. The method was that described by Jones et al. (1979) with the following modifications. Whole blood from a single volunteer was collected into a heparinized sterile plastic tube (Searle \& Co., Bucks., U.K.) and was used within $1 \mathrm{~h}$ of collection. The blood $(0.25 \mathrm{ml})$ was mixed with the bacterial suspension $(0.25 \mathrm{ml})$ in a sterile plastic tube and incubated in a shaking water bath at $41{ }^{\circ} \mathrm{C}, 37^{\circ} \mathrm{C}$ or $33{ }^{\circ} \mathrm{C}$. At time zero, $0.1 \mathrm{ml}$ samples were transferred into $0.9 \mathrm{ml}$ sterile distilled water, mixed well and left for $10 \mathrm{~min}$ at room temperature, to allow lysis of blood cells without killing the bacteria. Further samples were removed at timed intervals, and treated similarly. Samples were further diluted to $10^{-5}$ in nutrient broth and the viable count was determined. The percentage of surviving bacteria was calculated.

A sample $(0.05 \mathrm{ml})$ was removed from the phagocytic mixture after $30 \mathrm{~min}$ incubation, dried on a slide and stained with Giemsa stain. An estimate of the phagocytic index was made by counting the number of bacteria in 50 randomly dispersed PMN and also the number of PMN containing no bacteria. PMN which were actively involved in the ingestion of bacteria as judged by microscopy were designated active PMN. The results from a single experiment are presented (Table 1); replicate experiments carried out on separate blood samples gave similar results.

\section{RESULTS}

\section{Effect of temperature on the phagocytosis of exponential-phase and oxygen-depleted cells}

Exponential-phase cells showed a decrease in survival as the phagocytic temperature was increased from $33^{\circ} \mathrm{C}$ to $41{ }^{\circ} \mathrm{C}$ (Fig. 1). Incubation of bacteria in normal saline at $33{ }^{\circ} \mathrm{C}$ to $41{ }^{\circ} \mathrm{C}$ did not affect the viability (data not shown). Decrease in survival was also consistently observed in the oxygen-depleted $P$. cepacia as the temperature was increased from $37^{\circ} \mathrm{C}$ to $41{ }^{\circ} \mathrm{C}$, but there was only a slight difference between $33^{\circ} \mathrm{C}$ and $37^{\circ} \mathrm{C}$. Comparison of the killing of the exponential-phase and oxygen-depleted cells by whole blood at the same incubation temperature indicated that the latter were more resistant to the bactericidal action of the phagocytes. However, it was found that the oxygen-depleted cells were more easily engulfed than the exponential-phase cells by PMN (Table 1). Temperature seemed to have little effect on the 


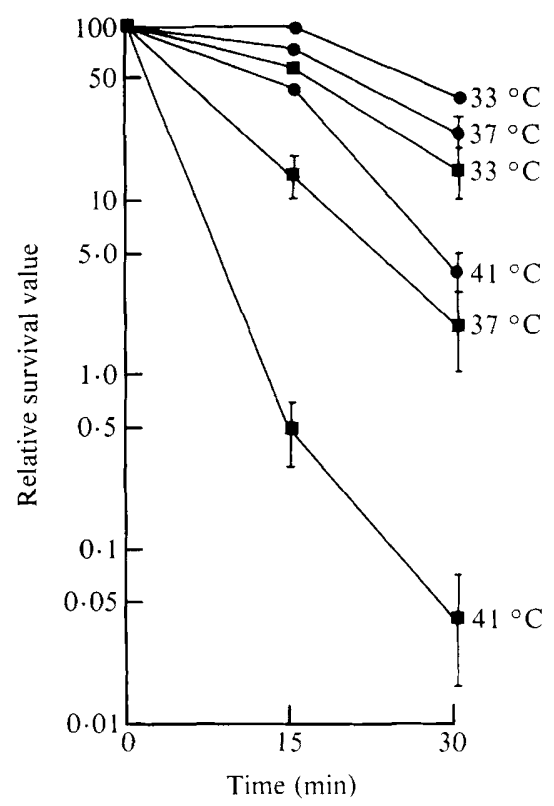

Fig. 1. Effect of temperature on killing of $\boldsymbol{P}$. cepacia by whole blood. $\boldsymbol{D}$, Exponential-phase cells; , oxygen-depleted cells. Survival values indicate viable counts relative to time zero $(=100)$.

Table 1. Engulfment of P. cepacia NCTC 10661 by PMN at three different temperatures

Depleting nutrient

Iron

Carbon

Nitrogen

Phosphate

Sulphate

Magnesium

Oxygen

Exponential phase*
Factors investigated $\dagger$

Percentage of active PMN

No. bacteria per active PMN

Percentage of active PMN

No. bacteria per active PMN

Percentage of active PMN

No. bacteria per active PMN

Percentage of active PMN

No. bacteria per active PMN

Percentage of active PMN

No. bacteria per active PMN

Percentage of active PMN

No. bacteria per active PMN

Percentage of active PMN

No. bacteria per active PMN

Percentage of active PMN

No. bacteria per active PMN
Temperature

\begin{tabular}{|c|c|c|}
\hline $41{ }^{\circ} \mathrm{C}$ & $37^{\circ} \mathrm{C}$ & $33^{\circ} \mathrm{C}$ \\
\hline 94 & 90 & 74 \\
\hline $7 \cdot 8 \pm \frac{1}{98}$ & $5 \cdot 5 \pm 0.9$ & $4 \cdot 1 \pm 0.7$ \\
\hline $10 \cdot 3 \pm \frac{2 \cdot 4}{96}$ & $9 \cdot \frac{8 \pm 1}{92} 1 \cdot 7$ & $\begin{array}{c}8 \cdot 0 \pm 1 \cdot 3 \\
90\end{array}$ \\
\hline $7 \cdot 0 \pm 1 \cdot 6$ & $4 \cdot 7 \pm \frac{1}{76} 1 \cdot 1$ & $4 \cdot 8 \pm 0.9$ \\
\hline $6 \cdot 3 \pm \frac{1}{95} 1 \cdot 4$ & $4 \cdot 7 \pm 0.9$ & $4 \cdot 1 \pm \frac{1}{92} 1 \cdot 1$ \\
\hline $8 \cdot 5 \pm 1 \cdot 6$ & $7 \cdot 7 \pm \frac{ \pm}{68} 1 \cdot 2$ & $5 \cdot 9 \pm \frac{55}{55} \cdot 1$ \\
\hline $\begin{array}{c}3 \cdot 7 \pm 0 \cdot 8 \\
100\end{array}$ & $2 \cdot 8 \pm 0 \cdot 8$ & $\begin{array}{c}2 \cdot 2 \pm 0 \cdot 7 \\
100\end{array}$ \\
\hline $10 \cdot 6 \pm 2 \cdot 7$ & $9 \cdot 8 \pm 2 \cdot 1$ & $9 \cdot 3 \pm 1 \cdot 8$ \\
\hline 92 & 90 & 90 \\
\hline $7 \cdot 5 \pm 1 \cdot 4$ & $5 \cdot 6 \pm 1 \cdot 0$ & $5 \cdot 0 \pm 0.9$ \\
\hline
\end{tabular}

* Exponential-phase cells: no specific nutrient was depleted.

$\dagger$ The data are given \pm S.D. (50 PMN counted).

engulfment of oxygen-depleted cells, possibly because they were readily engulfed even at the lowest temperature $\left(33^{\circ} \mathrm{C}\right)$. However, an increase in the number of bacteria engulfed per PMN was observed with exponential-phase cells as the phagocytic temperature was increased. It was also found that exponential-phase cells were much more susceptible to serum killing than oxygen-depleted cells (Fig. 3). 


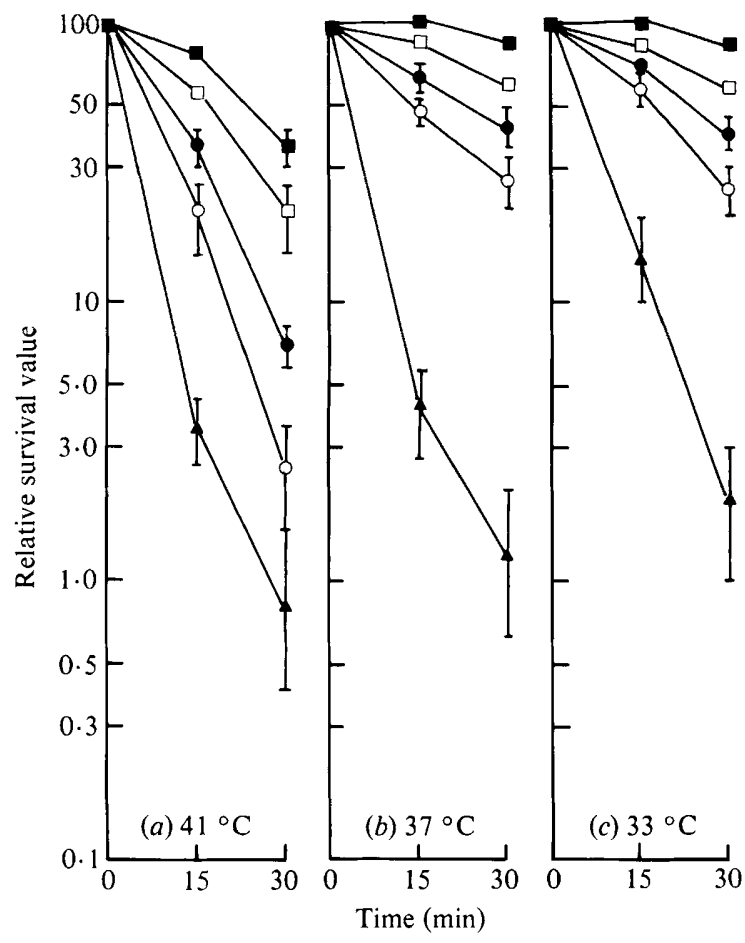

Fig. 2. Killing of $P$. cepacia by whole blood at $41^{\circ} \mathrm{C}($ a $), 37^{\circ} \mathrm{C}($ b $)$ and $33^{\circ} \mathrm{C}(\mathrm{c})$., $\mathrm{Mg}^{2+}$-depleted; $\square,\left(\mathrm{PO}_{4}\right)^{3-}$ or $\left(\mathrm{NH}_{4}\right)^{+}$-depleted (results not significantly different);,$\left(\mathrm{SO}_{4}\right)^{2-}$-depleted; $\mathrm{O}, \mathrm{Fe}^{2+}$ depleted; and $\mathbf{A}$, carbon-depleted cells. Survival values expressed as for Fig. 1.

\section{Effect of nutrient depletion on phagocytosis of $P$. cepacia at different temperatures}

Figure 2 shows the killing by whole blood of $P$. cepacia grown under six different nutrient depletions at three different temperatures. Resistance to killing by whole blood at any temperature was found to be in the following order: carbon- $<$ iron- $<$ sulphate- $<$ nitrogen- or phosphate- $<$ magnesium-depleted cells. Carbon-depleted cells were also found to be most easily engulfed by PMN (Table 1). There was only a slight effect of temperature upon the number of carbon-depleted cells engulfed per PMN. Magnesium-depleted cells were not only the most resistant to killing but were also the least susceptible to engulfment of all the nutrient depletions studied. The other nutrient-depleted cells were intermediate in sensitivity between carbon- and magnesium-depleted cells.

Effect of nutrient depletions on serum killing of P. cepacia at $37^{\circ} \mathrm{C}$

The bactericidal action of human serum on $P$. cepacia grown under different nutrient depletions is shown in Fig. 3. Carbon-depleted and exponential-phase cells were much more sensitive than iron- or oxygen-depleted cells. Comparison of killing in whole blood (Figs 1 and 2) and in serum (Fig. 3) shows that whole blood was at least six- to tenfold more effective than serum in eliminating the organism after $30 \mathrm{~min}$ incubation.

\section{DISCUSSION}

The rate of killing of $P$. cepacia by the combined action of PMN and serum factors in whole blood increased with increasing temperature from $33^{\circ} \mathrm{C}$ to $41^{\circ} \mathrm{C}$. The nutrient conditions under which the cells were grown had a dramatic effect upon the susceptibility to blood killing. The order of resistance of cells grown under different nutrient depletions was carbon $<$ iron $<$ 


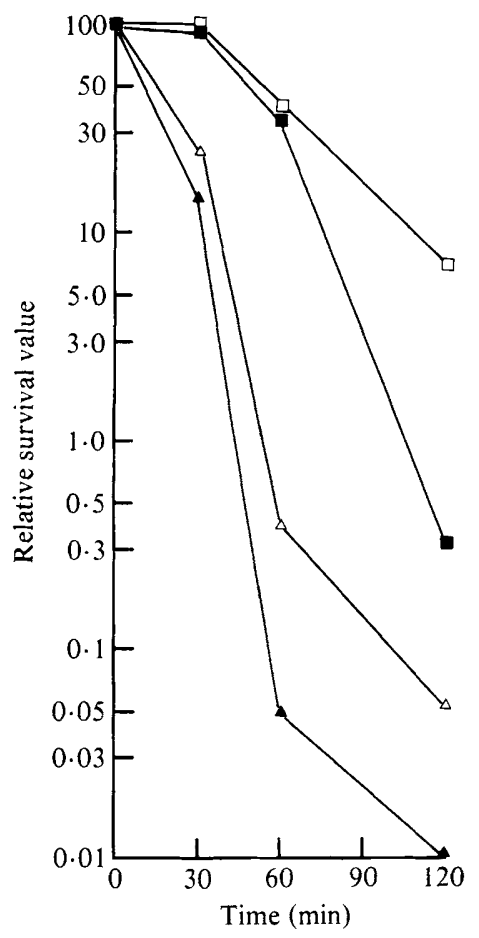

Fig. 3. Killing of $\boldsymbol{P}$. cepacia by human serum at $37^{\circ} \mathrm{C}$. $\square$, oxygen-depleted; $\boldsymbol{\square}, \mathbf{F e}^{2+}$-depleted; $\triangle$, exponential-phase; and $\boldsymbol{\Delta}$, carbon-depleted cells. Survival values expressed as for Fig. 1.

nitrogen or phosphate $<$ magnesium. In the case of sulphate-depleted cells the possibility of excess phosphate or chloride contributing to phenotypic changes cannot be ruled out. Engulfment and killing should be considered as two separate events. Cells might be easily engulfed and easily killed by PMN. On the other hand, they might also be engulfed easily but be resistant to killing inside the PMN. Possibly the physicochemical surface properties of oxygendepleted cells render them susceptible to engulfment but resistant to chemical and enzymic attack inside the PMN or serum. Differences in the composition and structure of the outer membrane might possibly explain their difference in susceptibility to the bactericidal action of PMN or serum alone (Costerton et al., 1979). Temperature had little effect upon the rapid rate of killing by blood of the very sensitive carbon-depleted cells. Engulfment of the different nutrientdepleted cells reflected the same pattern of sensitivity found for killing by blood. Carbondepleted cells showed the greatest engulfment and magnesium-depleted cells were engulfed the least. In all cases engulfment increased with increasing temperature. The results with irondepleted cultures have special significance in view of the role of iron in vivo (Bullen, 1981; Weinberg, 1978).

The results confirm the observations by Finch \& Brown (1978) that the growth environment has a significant effect on the killing of micro-organisms by PMN plus serum or by serum alone. Depending on the nutrient depletion, $P$. cepacia can be highly sensitive to blood killing (e.g. carbon-depleted cells) or highly resistant (e.g. magnesium-depleted cells at $33^{\circ} \mathrm{C}$ ). Presumably the wide range of sensitivity shown by the organism reflects the phenotypic variation in cell envelope composition which has been shown with many organisms to depend upon growth rate and specific nutrient depletion (Brown, 1977; Costerton et al., 1979; Finch \& Brown, 1978). The protein and phospholipid composition of the outer membrane of $P$. cepacia varied considerably with nutrient depletion (Anwar et al., 1983). Variation in the ability of PMN to engulf these different nutrient-depleted cells might be due to changes in the surface free energy of the cells 
resulting from these alterations in the chemical composition of the envelope. Surface free energy is thought to be an important factor in the engulfment process (Van Oss et al., 1975; Van Oss, 1978; Stendahl et al., 1979). Altered sensitivity to opsonization is another possibility. Cells grown under different nutrient depletions might possibly have altered surface antigens which would be opsonized to different extents. For example, the heterogeneity of the lipopolysaccharide as suggested by several workers (Goldman \& Leive, 1980; Palva \& Makela, 1980; Day \& Marceau-Day, 1982) in other Gram-negative bacteria might also occur in P. cepacia as a result of phenotypic variation. This alteration would possibly affect the degree of opsonization.

We believe that future studies should use cells grown under defined conditions which closely mimic those occurring in vivo (Brown, 1977). For example, the amount of free iron available for bacterial growth in body fluids is very low, of the order of $10^{-18} \mathrm{M}$ (Weinberg, 1978). Under these conditions cells are likely to be growing slowly under iron limitation (Bullen, 1981; Weinberg, 1978). Undoubtedly similar considerations apply in the area of antigen and vaccine production.

Helpful discussions with Drs R. J. Jones and E. A. Roe are gratefully acknowledged.

\section{REFERENCES}

Anwar, H., Brown, M. R. W., Cozens, R. M. \& LAMBERT, P. A. (1983). Isolation and characterization of the outer and cytoplasmic membranes of Pseudomonas cepacia. Journal of General Microbiology 129, 499-507.

Ballard, R. W., Palleroni, N. J., Doudoroff, M., Stanier, R. Y. \& MANDEL, M. (1970). Taxonomy of the aerobic Pseudomonads: Pseudomonas cepacia, $P$. marginata, $P$. alliicola and $P$. caryophylli. Journal of General Microbiology 60, 199-214.

BEVERIDGE, T. J. (1980). Bacterial structure and its implications in the mechanisms of infection: a short review. Canadian Journal of Microbiology 26, 643653.

Brown, M. R. W. (1975). The role of the cell envelope in resistance. In Resistance of Pseudomonas aeruginosa, pp. 71-107. Edited by M. R. W. Brown. London: John Wiley.

Brown, M. R. W. (1977). Nutrient depletion and antibiotic susceptibility. Journal of Antimicrobial Chemotherapy 3, 198-201.

Bullen, J. J. (1981). The significance of iron in infection. Reviews of Infectious Diseases 3, 11271138.

Costerton, J. W., Brown, M. R. W. \& Sturgess, J. M. (1979). The cell envelope: its role in infection. In Pseudomonas aeruginosa: Clinical Manifestation of Infection and Current Therapy, pp. 41-62. Edited by R. G. Doggett. New York: Academic Press.

DAY, D. F. \& MARCEAU-DAY, M. L. (1982). Lipopolysaccharide variability in Pseudomonas aeruginosa. Current Microbiology 7, 93-98.

Finch, J. E. \& BRown, M. R. W. (1978). Effect of growth environment on Pseudomonas aeruginosa killing by rabbit polymorphonuclear leukocytes and cationic proteins. Infection and Immunity 20, 340346.

Garvey, G. J. \& Neu, H. C. (1975). Infective endocarditis. Postgraduate Medicine 58, 107-113.
Goldman, R. C. \& Leive, L. (1980). Heterogeneity of antigenic-side-chain length in lipopolysaccharide from Escherichia coli $\mathrm{O} 111$ and Salmonella typhimurium LT2. European Journal of Biochemistry 107, $145-153$.

Jones, R. J., Roe, E. A. \& Gupta, J. L. (1979). Controlled trials of a polyvalent Pseudomonas vaccine in burns. Lancet ii, 977-983.

Mackowiak, P. A., Marling-Caron, M. \& Cohen, R. L. (1982). Effects of temperature on antimicrobial susceptibility of bacteria. Journal of Infectious Diseases 145, 550-553.

Mandell, G. L. (1975). Effect of temperature on phagocytosis by human polymorphonuclear neutrophils. Infection and Immunity 12, 221-223.

Miles, A. A. \& MisRA, S. S. (1938). The estimation of the bactericidal power of blood. Journal of Hygiene 38, 732-748.

Palva, E. T. \& Makela, P. H. (1980). Lipopolysaccharide heterogeneity in Salmonella typhimurium analyzed by sodium dodecyl sulphate/polyacrylamide gel electrophoresis. European Journal of Biochemistry 107, 137-143.

Phillips, I. \& Eykyn, S. (1971). Pseudomonas cepacia (multivorans) septicemia in an intensive care unit. Lancet i, 375-377.

Roberts, N. J. (1979). Temperature and host defence. Microbiological Reviews 43, 241-259.

Roberts, N. J. \& Steigbigel, R. T. (1977). Hyperthermia and human leukocyte functions: effects on response of lymphocytes to mitogen and antigen and bactericidal capacity of monocytes and neutrophils. Infection and Immunity 18, 673-679.

SMITH, H. (1977). Microbial surfaces in relation to pathogenicity. Bacteriological Reviews 41, 475-500.

Speller, D. G., Stephens, M. E. \& Viant, A. C. (1971). Hospital infection by Pseudomonas cepacia. Lancet i, 798-799. 
Stendahl, L., Norman, B. \& Edebo, L. (1979). Influence of $O$ and $K$ antigens on the surface properties of $E$. coli in relation to phagocytosis. Acta pathologica scandinavica, Section B 87, 85-91.

VAN Oss, C. J. (1978). Phagocytosis as a surface phenomenon. Annual Review of Microbiology 32, 1939.

Van Oss, C. J., Gillman, C. F. \& Neumann, A. W. (1975). Phagocytic Engulfment and Cell Adhesiveness as Cellular Surface Phenomena. New York: Marcel Dekker.

WEINBERG, E. D. (1978). Iron and infection. Microbiological Reviews 42, 45-66.

Weinstein, R. A., Emori, T. G., ANDERSon, R. L. \& StamM, W. E. (1976). Pressure transducers as a source of bacteremia after open heart surgery. Report of outbreak and guidelines for prevention. Chest 69, 338-344. 